\title{
CHARACTERISTICS OF THE MAIN DIRECTIONS OF INCLUSIVE REHABILITATION AND SOCIAL TOURISM IN UKRAINE
}

\author{
Nataliya BIELOUSOVA \\ National Aviation University, Kyiv, Ukraine \\ belousova-69@ukr.net
}

\begin{abstract}
The article deals with the development of inclusive rehabilitation and social tourism as a segment of social tourism, which, unfortunately, is practically not developed in Ukraine. The proposed assessment of the main directions for the development and implementation of inclusive tourism in Ukraine provided a description of each of these areas. We have established that practical rehabilitation and social activities for inclusive people, who may be potential tourists, can be divided into five main areas: 1) medical and health tourism; 2) cultural and educational tourism; 3) family and youth tourism in Ukraine; 4) professional and labor direction of rehabilitation activities; 5) non-Olympic physical culture and sports.

Key words: inclusive tourism, people with disabilities, rehabilitation and social activities, directions of inclusive and rehabilitation assistance.
\end{abstract}

DOI: https://doi.org/10.17721/2413-7154/2019.81.18-28

UDC: $378.1: 615.825$

Received: February 4, 2019.

Revised: May 23, 2019.

Accepted: June 10, 2019.

\section{ХАРАКТЕРИСТИКА ОСНОВНИХ НАПРЯМІВ ІНКЛЮЗИВНОГО РЕАБІЛІТАЦІЙНО-СОЦІАЛЬНОГО ТУРИЗМУ В УКРАЇНІ}

\author{
Наталія БєлоусовА \\ Національний авіаційний університет, м. Київ, Україна \\ belousova-69@ukr.net
}

\begin{abstract}
Анотація: В статті розглянуто питання розвитку інклюзивного реабілітаційно-соціального туризму як сегменту соціального туризму, який в Україні, на жаль, практично не розвинений. Запропонована оцінка основних напрямів розвитку та впровадження інклюзивного туризму в Україні та надана локанічна характеристика кожного з цих напрямів. Нами встановлено, що практичну реабілітаційно-соціальну діяльність для інклюзивних осіб, які можуть бути й потенційними туристами, можна поділити на пять основних напрямів: 1) лікувально-оздоровчий - охоплює реабілітаційні послуги всіх людей з інклюзією, але особлива увага звертається на реабілітацію людей з інвалідністю по відновленню опорно-рухового апарату, в тому числі учасників військових дій на сході України, постраждалих від цих дій та людей, які отримали інвалідність внаслідок антитерористичної операції (АТО); 2) концепції культурно-пізнавального туризму знайшли своє комплексне відображення в наукових роботах професора М. Драгічевич-Шешич, результатом яких стала класифікація культурно-пізнавального туризму на види, типи, об'єкти, які відрізняються найбільшою привабливістю і виступають головним засобом задоволення потреб пізнавальнокультурної рекреації; 3) сімейно-молодіжний туризм в Україні $\epsilon$ особливо актуальним, оскільки має патріотичновиховне значення та дає змогу реалізувати конституційне право кожної людини на відпочинок, що підтверджується науково-дослідними роботами В. Аксанюк, Ю. Грабовського, Ю. Кузнецова, С. Нікітенко, В. Орловської, В. Пестушко, Н. Савченко, А. Шипко та ін.; 4) професійно-трудовий напрям - зможе надати можливість освоїти та надалі застосувати нові види професійних та трудових навичок, для продовження трудової діяльності, в тому числі і надомної праці; 5) не олімпійського фізкультурно-спортивного спрямування - оптимізація дій, скерованих на інтеграцію інклюзивних категорій людей до активного життя у суспільстві, покращення їх фізичного і функціонального стану та відновлення їх працездатності засобами фізичної культури і спорту.
\end{abstract}

Ключові слова: інклюзивний туризм, люди з інвалідністю, реабілітаційно-соціальна діяльність, напрями інклюзивно-реабілітаційної допомоги. 
Introduction. In the system of development of the tourist sphere of the world, a special place today belongs to inclusive tourism as a segment of social tourism, which in Ukraine, unfortunately, is practically not developed.

Inclusive tourism is considered by the world community as a modern type of tourism, which allows including any person in tourist activities, regardless of their physical abilities and subject to the availability of tourist infrastructure facilities $[3 ; 6]$.

The purpose of the article is to demonstrate the close relationships of the previously studied areas in the framework of the rehabilitation and social process for inclusive groups with the use of tourism services an attempt to justify inclusive rehabilitation and social tourism as a new direction, taking into account the internal political, social and everyday life and mentality of Ukrainian society.

In Ukraine, inclusive rehabilitation and social tourism is understood as a system of measures aimed at providing, above all, people with disabilities the opportunity to restore and develop their physical, social, spiritual, creative and intellectual level in order to promote further integration into society. Although according to world standards, inclusive tourist groups include: pensioners, families with many children, the poor, people with a low social standard of living, etc. Inclusive tourism structurally includes various types of rehabilitation and social services, namely: medical, psychological, psychological, educational, professional, labor, physical culture, sports, physical, social and other social events. This type of tourism is gaining momentum all over the world, as evidenced by statistical data (7\% of tourists from all over the world are people with disabilities) [1; 4]. The demand for the "accessible to all" tourism market will grow in the coming years.

A special feature of tourism as a means of recreation and knowledge of the surrounding world is its wide coverage of almost all types of social and physical rehabilitation (Table 1.).

According to the provided tabular information (table 1), a cartographic model of the territorial location of sanatorium-resort institutions in the areas of treatment of persons with disabilities was constructed (Fig. 1).

Given the multifaceted nature of social rehabilitation in working with people who fall under the status of people with inclusion and relying on scientific research over the past five years (2014-2018), we were able to identify five main areas in the system of inclusive rehabilitation and social tourism (IRST):

- therapeutic and health;

- cultural and educational;

- family and youth;

- professional labor;

- non-Olympic physical culture and sports.

Table 1.

Model of social and physical rehabilitation of persons with limited health opportunities by means of inclusive tourism

\begin{tabular}{|l|l|l|}
\hline \multicolumn{1}{c|}{$\begin{array}{c}\text { Type of } \\
\text { rehabilitation }\end{array}$} & \multicolumn{1}{|c|}{ Rehabilitation impact } & \multicolumn{1}{c|}{ Operating factors } \\
\hline \multirow{5}{*}{$\begin{array}{l}\text { Physical } \\
\text { rehabilitation }\end{array}$} & Improvement & $\begin{array}{l}\text { Priving activity, health-improving technologies of adaptive } \\
\text { physical culture }\end{array}$ \\
\cline { 2 - 3 } & $\begin{array}{l}\text { Socio-communicative } \\
\text { adaptation }\end{array}$ & $\begin{array}{l}\text { Aesthetic effects of natural and cultural environment, the } \\
\text { impression of tourist trips }\end{array}$ \\
\cline { 2 - 3 } & $\begin{array}{l}\text { Shanges in the nature and social circle, activities in small groups, } \\
\text { changes in the social role }\end{array}$ \\
\cline { 2 - 3 } & $\begin{array}{l}\text { Socio-ecological } \\
\text { rehabilitation }\end{array}$ & $\begin{array}{l}\text { Activities aimed at self-sufficiency, self-care and the organization } \\
\text { of life in a tourist trip }\end{array}$ \\
\hline \multirow{5}{*}{$\begin{array}{l}\text { Social } \\
\text { rehabilitation }\end{array}$} & $\begin{array}{l}\text { Socio-communicative } \\
\text { adaptation }\end{array}$ & $\begin{array}{l}\text { Changes in the nature and social circle, activities in small groups, } \\
\text { changes in the social role }\end{array}$ \\
\cline { 2 - 3 } & $\begin{array}{l}\text { Social and domestic } \\
\text { rehabilitation }\end{array}$ & $\begin{array}{l}\text { Activities aimed at self-sufficiency, self-care and the organization } \\
\text { of life in a tourist trip }\end{array}$ \\
\cline { 2 - 3 } & $\begin{array}{l}\text { Socio-ecological } \\
\text { rehabilitation }\end{array}$ & Mastering the technologies of functioning in various habitats \\
\cline { 2 - 3 } & $\begin{array}{l}\text { Socio-pedagogical } \\
\text { rehabilitation }\end{array}$ & Mastering new knowledge, skills and abilities \\
\cline { 2 - 3 } & Socio-cultural rehabilitation & Excursions, songs, conversations, exhibitions, photo contests, etc. \\
\cline { 2 - 3 } & $\begin{array}{l}\text { Socio-psychological } \\
\text { rehabilitation }\end{array}$ & $\begin{array}{l}\text { Social activation in the process of tourist activities, monitoring } \\
\text { the success of other persons with disabilities, the transformation } \\
\text { of worldview }\end{array}$ \\
\hline
\end{tabular}

*Compiled from materials [2, p.205-213] 


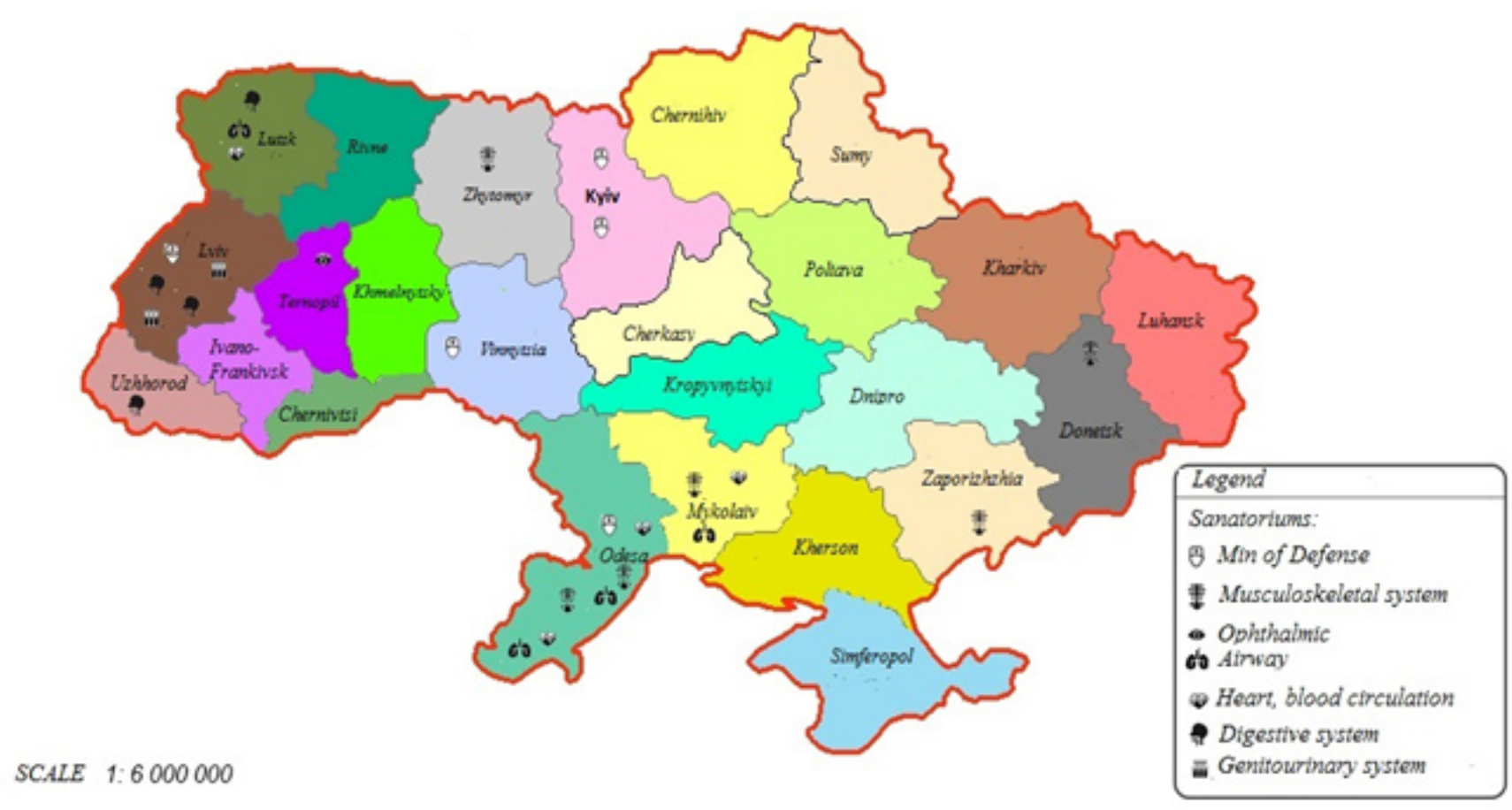

Figure 1. Sanatorium-resort institutions for treatment of disabled people

Let us dwell on each of the types of IRCT, according to the territorial distribution of those institutions or institutions operating in the territory of Ukraine, within the framework of specialized or comprehensive assistance to the categories of rehabilitators for the provision of rehabilitation services.

\section{Medical and recreational direction of IRST}

In Ukraine, the process of becoming a model of medical and social assistance to people with inclusion continues, which indicates significant structural changes in the country, including in relation to the needs of people with disabilities, for whom the main task is integration into modern society.

At the stage of reforming the healthcare industry of Ukraine, among various types of diseases, special attention will be paid to the rehabilitation of people with disabilities, where the main focus of rehabilitation activities is the restoration of the musculoskeletal system.

In addition to the liquidators of the accident at the Chernobyl nuclear power plant and the disabled category of general disease, Ukraine has a new category of people with disabilities - participants and victims of the ATO.

This list of rehabilitants can be attributed to citizens who refused to remain in the occupied territory, having left for different regions of Ukraine. These people have significant psychological trauma, having lost their property, business, not having a sense of peace and security, opportunities for a decent life and a comfortable future. The problem is acquiring significant quantitative and qualitative dimensions.

The main performers of rehabilitation programs, first of all, are [1;25]:

-rehabilitation and therapeutic (treatment-andprophylactic) institutions;
- rehabilitation and health institutions (centers);

- rehabilitation and prosthetic facilities.

Today, Ukraine offers rehabilitation services for persons with disabilities with the consequences of injuries and diseases of the spine, spinal cord and general diseases following sanatoriums (Table 2) [12].

In addition, according to the developed and approved by Order No. 471 of 04/04/2018 "On the establishment of the marginal cost of a voucher (bed-day) in 2018", it was registered in the Ministry of Justice of Ukraine on April 17, 2018 under No. 461/31913 treatment is offered to some privileged categories of citizens, namely [11]:

- persons with disabilities as a result of the war from among the affected participants of the Revolution of Dignity and participants in the antiterrorist operation, persons with disabilities as a result of a common disease and persons with disabilities since childhood;

- persons with disabilities with the consequences of injuries and diseases of the spine and spinal cord (persons with disabilities as a result of the war among the affected participants of the Revolution of Dignity and participants of the antiterrorist operation,persons with disabilities as a result of a common disease and persons with disabilities since childhood)

- to participants of military operations and participants of war from among the participants of the antiterrorist operation, injured participants of the Revolution of Dignity;

- to citizens accompanying persons with disabilities group I (except for persons with disabilities with consequences of injuries and diseases of the spine and spinal cord) (Table 3).

As a result of the statistical data provided above, it can be concluded that the quantitative indicators of medical and health institutions are not able to meet 
The sanatorias by inclusive rehabilitation directions

\begin{tabular}{|l|c|c|}
\multicolumn{1}{|c|}{ Name of Sanatoria } & Location & Conformation \\
\hline SOE 'Sanatorium Resort Complex', rehabilitation center & Donetsk Region & Slovyansk Resort \\
\hline SOE 'The Clinic center named by Pirogov' & Odesa Region & CJSC 'Ukrprofzdorovnitsia' \\
\hline Sanatorium 'Orizont' & Odesa Region & SOE 'South Resort service' \\
\hline LLC ‘Sanatorium Arctica' & Zaporizhzhia Region & Private Enterprise \\
\hline LLC 'Sanatorium Borisfen' & Mykolaiv Region & Private Enterprise \\
\hline The central military clinical Sanatorium 'Khmilnyk' & Vinnytsia Region & $\begin{array}{c}\text { The Ministry of Defense of } \\
\text { Ukraine }\end{array}$ \\
\hline $\begin{array}{l}\text { The Center of medical rehabilitation and treatment 'Puscha } \\
\text { Vodytsia' }\end{array}$ & Kyiv Region & $\begin{array}{c}\text { The Ministry of Defense of } \\
\text { Ukraine }\end{array}$ \\
\hline $\begin{array}{l}\text { The Sanatorium department of Military and clinic center of The } \\
\text { Central Region }\end{array}$ & Kirovohrad Region & $\begin{array}{c}\text { The Ministry of Defense of } \\
\text { Ukraine }\end{array}$ \\
\hline $\begin{array}{l}\text { The medical rehabilitation center ‘Truskavetskyi” } \\
\text { Lviv Region }\end{array}$ & $\begin{array}{c}\text { The Ministry of Defense of } \\
\text { Ukraine }\end{array}$ \\
\hline
\end{tabular}

*Compiled from materials $[1 ; 5]$

Table 3

Sanatorium and resort facilities providing their services to privileged categories of citizens (general sick people with disabilities and anti-terrorist operations participants)

\begin{tabular}{|c|c|c|c|}
\hline $\begin{array}{c}\text { Item } \\
\text { number }\end{array}$ & $\begin{array}{c}\text { The name of the } \\
\text { sanatorium }\end{array}$ & Address & $\begin{array}{c}\text { Treatment profiles (as per medical } \\
\text { practice license) }\end{array}$ \\
\hline 1 & LLC 'Sanatorium Barvinok' & $\begin{array}{lrr}\text { Ternopil } & \text { Region, } & \text { Zboriv } \\
\text { District, } & \text { Mshanets } & \text { Village, } \\
\text { Hamlet Manyuki, 2 } & \\
\end{array}$ & eye treatment \\
\hline 2 & $\begin{array}{l}\text { SOE 'Shipyard named by } \\
61 \text { Komuniara Sanatorium } \\
\text { Ingul' }\end{array}$ & $\begin{array}{l}\text { Mykolaiv, Heroiv Ukrayiny } \\
\text { Avenue, } 6 \mathrm{a}\end{array}$ & $\begin{array}{l}\text { respiratory system treatment, support } \\
\text { and movement organs treatment }\end{array}$ \\
\hline 3 & $\begin{array}{l}\text { SOE 'South Resort Service ' } \\
\text { Sanatorium 'Orizont' }\end{array}$ & $\begin{array}{l}\text { Odesa Region, Bilhorod- } \\
\text { Dnistrovskyi } \quad \text { District, } \\
\text { settlement Serhiivka, Haharina } \\
\text { Street, 1-a }\end{array}$ & $\begin{array}{l}\text { respiratory system treatment, support and } \\
\text { movement organs treatment, circulatory } \\
\text { diseases }\end{array}$ \\
\hline 4 & SOE ‘Polyana' & $\begin{array}{l}\text { Zakarpattia } \quad \text { Region, } \\
\text { Svaliavskyi District, Polyana } \\
\text { Village, Dukhnovycha Street, } \\
104\end{array}$ & treatment of the digestive system \\
\hline 5 & $\begin{array}{l}\text { LLC Seaside Sanatorium } \\
\text { named by Lazo }\end{array}$ & $\begin{array}{l}\text { Odesa Region, settlement } \\
\text { Serhiivka, Naberezhna, } 3\end{array}$ & $\begin{array}{l}\text { respiratory system treatment, support and } \\
\text { movement organs treatment, circulatory } \\
\text { diseases }\end{array}$ \\
\hline 6 & $\begin{array}{l}\text { ME Zhytomirskyi regional } \\
\text { treatment center of radiation } \\
\text { protection for children and } \\
\text { adults 'Denyshi' }\end{array}$ & $\begin{array}{l}\text { Zhytomir Region, Zhytomir } \\
\text { District, Denyshi Village }\end{array}$ & support and movement organs treatment \\
\hline 7 & $\begin{array}{l}\text { PJSC Sanatorium Hotel } \\
\text { complex 'Dnipro Beskyd' }\end{array}$ & $\begin{array}{l}\text { Lviv Region, Truskavets, } \\
\text { Drohobytska Street, } 33\end{array}$ & $\begin{array}{l}\text { treatment of the digestive system, } \\
\text { nephrology }\end{array}$ \\
\hline 8 & $\begin{array}{l}\text { PJSC 'Truskavetskurort' } \\
\text { Sanatorium 'Almaz' }\end{array}$ & $\begin{array}{l}\text { Lviv Region, Truskavets, } \\
\text { Drohobycha Blvd, } 2\end{array}$ & $\begin{array}{l}\text { treatment of the digestive system, } \\
\text { nephrology }\end{array}$ \\
\hline 9 & $\begin{array}{l}\text { ME Sanatorium of Mother } \\
\text { and Child 'Prolisok' }\end{array}$ & $\begin{array}{l}\text { Volyn Region, Kivertsivskyi } \\
\text { District, Hremyache Village }\end{array}$ & $\begin{array}{l}\text { treatment of cardiovascular system, } \\
\text { gastrointestinal tract, respiratory, } \\
\text { circulatory system }\end{array}$ \\
\hline 10 & $\begin{array}{l}\text { SOE 'Clinical Sanatorium } \\
\text { named by Pirogov' for } \\
\text { spinal disabilities }\end{array}$ & Odesa Region, Kuyalnik & support and movement organs treatment \\
\hline
\end{tabular}

*Compiled from materials $[1 ; 16 ; 22]$ 
Classification of cultural cognitive tourism by M. Dragichevich-Sheshich

\begin{tabular}{|c|c|}
\hline Group & Type \\
\hline Historical travels & $\begin{array}{c}\text { journey into history, } \\
\text { historical reenactment journey, } \\
\text { religious journeys, } \\
\text { studies in global history }\end{array}$ \\
\hline Geographic travels & comprehensive specialized \\
\hline Artistic travels & in order to study any direction in art, etc. \\
\hline
\end{tabular}

*Compiled from materials $[1 ; 24]$

Table 5

Classification of Cultural and Cognitive Recreational Resources

\begin{tabular}{|l|l|}
\hline $\begin{array}{c}\text { Types of Cultural and } \\
\text { Cognitive Recreational } \\
\text { Resources }\end{array}$ & \multicolumn{1}{c|}{ Resources } \\
\hline Material & $\begin{array}{l}\text { - varieties of historical and cultural monuments (monuments of archeology, history, } \\
\text { architecture and urban planning, monumental art) } \\
\text { - museums } \\
\text { - museum-sanctuaries } \\
\text { - memorial estate }\end{array}$ \\
\hline Non-material & $\begin{array}{l}\text { - customs } \\
\text { - traditions } \\
\text { - rites } \\
\text { - oral literature }\end{array}$ \\
\hline
\end{tabular}

*Compiled from materials [24]

Table 6

Classification of cultural-historical objects

\begin{tabular}{|c|l|}
\hline $\begin{array}{c}\text { Material cultural and } \\
\text { historical objects }\end{array}$ & $\begin{array}{l}\text { - a set of means of production; } \\
\text { - other material values of society at each historical stage of its development }\end{array}$ \\
\hline & $\begin{array}{l}\text { - a set of achievements of society in education; } \\
\text { - the totality of the achievements of society in science; } \\
\text { Spiritual cultural and } \\
\text { historical objects } \\
\text { - the tofachievements of society in art; } \\
\text { - a set of achievements of society in the organization of state and public life, } \\
\text { in work and life }\end{array}$ \\
\hline
\end{tabular}

*Compiled from materials $[10 ; 24]$

the rehabilitation needs of people who need it, even if there are listed working institutions that provide professional assistance.

\section{Cultural and cognitive rehabilitation}

Cultural and educational tourism is the basis for scientific research of culture, as well as a means of attracting individuals to the culture. In the development of the concept of cultural and educational tourism a significant contribution was made by the research of Professor M. Dragicevich-Sheshich, the result of which was the classification of cultural and educational tourism (Table 4).

In foreign literature, cultural and educational tourism has the following interpretations:

1. As an ideal arena for exploring the nature of cultural reproduction; 2. Consumption by tourists of art, artistic heritage, folklore and a number of other cultural manifestations. 
Cultural and educational tourism has its own resources and types of cultural and educational resources: subject and non-subject (Table 5).

Thematic cultural and educational recreational resources are used in the form of recreational services in the activities of museums and museums-reserves. And the cultural heritage of the Ukrainian people reflects the peculiarities of traditions, rituals, customs, originality of oral folklore, and the like. An intermediate position in the classification of cultural and educational recreational services is occupied by centers of folk arts and crafts.

Cultural and educational resources are a prerequisite for the organization of cultural and educational types of recreational services, optimizing recreational activities in general, performing quite serious educational functions.

Cultural and historical objects are divided into (see Table 6) material and non-material.

In fact, the entire heritage of the historical past of the Ukrainian people, which is researched and evaluated by scientific methods, can be attributed to cultural and educational resources, if they have social value and can be used with existing technical and material resources to meet the recreational needs of a significant number of people during a certain time [24].

Among cultural and educational objects, the leading role belongs to historical and cultural monuments, which are the most attractive and, on this basis, serve as the main means of satisfying the needs of cognitive-cultural recreation.

The cultural and historical prerequisites of the recreational industry include other objects related to the history, culture and modern activities of people: original enterprises of industry, agriculture, transport, theaters, scientific and educational institutions, sports facilities, botanical gardens, zoos, ethnographic and folklore attractions, handicrafts, folk customs, holiday rituals, etc. [10]. All objects used in cognitive-cultural recreation, are divided into two groups: mobile and stationary [24].

Consumption of mobile recreational resources is associated with visits to museums, libraries and archives, where they are usually concentrated. From the position of cognitive and cultural recreation, it is important that the fixed objects are independent solitary or group formations.

For example, to assess the use of cultural and historical objects, a typology was taken based on the informational essence of cultural and historical objects: uniqueness, typicalness among objects of this type, educational and educational value, attractiveness [24].

According to the degree of organization, objects are divided into specially organized and unorganized for display. Organized objects require more time for inspection, as they are the purpose of the inspection and form the basis of the excursion, unorganized - they serve as a general plan accompanying the excursion, a background that is covered by one glance without detailed consideration.

According to the location of the tourists, the objects are divided into interior and exterior. The total time of inspection of exterior objects is always greater than the time of inspection of interior objects [24].
Due to the wide spatial-spatial spectrum of the historical and cultural heritage of the Ukrainian people, almost every region of Ukraine has the ability to provide re-distribution services to inclusive tourists actively using cultural and educational resources.

Family and youth direction of rehabilitation of people with inclusion

Family and youth tourism is one of the most common areas of the global industry. Y. Grabovsky [7], Y. Kuznetsov [15], S. Nikitenko [13], V. Pestushko [14], etc. made a significant contribution to the substantiation of the need for the development of youth and children's tourism.

Tourist youth is the most unpretentious sociodemographic group, for which quality indicators in food centers and service levels in hotels are secondary, but prefer comfort to affordable prices, an interesting, varied and rich cultural and leisure program of stay, which corresponds to their age and personal tastes.

The development of youth and family tourism in Ukraine today is especially important, since it has a patriotic educational value and allows to realize the constitutional right of every person to rest.

Creating a youth tourism infrastructure solves several urgent problems:

1) for the person:

- health promotion;

- the ability to travel;

- raising the educational and cultural level;

- professional orientation;

2) for the state:

- development of tourism as an important sector of the economy;

- employment; raising the status of a country at the international level;

- the recovery of the population [17, p. 3-5].

Youth tourism "as a means of forming a personality, and as a segment of the tourism industry of Ukraine" [17, p.3] actively influences the development of the economy, the restructuring of the economy and changing priorities, including social, increasing the contribution to the general economic level of well-being of the population of Ukraine.

This approach is especially important for families with a family with a child with a disability or rehabilitators of other groups and nosologies with certain physical, psychological, post-traumatic and other problems that require further adaptation to the society. A significant disadvantage in working with these groups of inclusive people is the practical absence of adapted or adapted tourist routes that would take into account all the features of a particular nosological group.

Youth tourism, as a component of the system of youth policy in Ukraine, has great prospects for the internal development of tourism, where tourism organizations play a significant role, which are precisely the direction of youth tourism.

Professional and labor rehabilitation of people of inclusive groups

The occupational and labor rehabilitation of the IRCT types concerns, first of all, the participants of the anti- 
terrorist operation, displaced persons from the combat zone and people with disabilities.

They are provided with psychological rehabilitation as a complex of measures, carried out with the aim of preserving, restoring or compensating for impaired mental functions, qualities, personal and social status of a person, facilitating psychosocial adaptation to a changed life situation, understanding the experience gained in an extreme situation, and applying it in life.

The purpose of psychological rehabilitation are:

1) the preservation and physical and mental health of recipients of services;

2) the achievement of socio-psychological wellbeing;

3) reduction in the frequency and severity of the effects of military trauma suffered in the form of acute stress reactions;

4) prevention of disability;

5) prevention of aggressive and self-destructive behavior

The main objectives of the psychological rehabilitation are:

1) diagnosis and normalization of the mental functions of the recipient of services;

2) restoration of impaired (lost) mental functions to the optimal level of their severity;

3) correction of the identity of the recipient of services to ensure its effective functioning in society;

4) the provision of assistance in the establishment (restoration) of constructive relations in the family and society;

5) restoration of adaptive mechanisms in extreme (combat) actions;

6) mastering self-regulation and stress management (sedation)

7) prevention of psychological trauma and mental disorders;

8) carrying out psycho-prophylactic and psychocorrectional work with the family of the recipient of services;

9) the formation of positive reactions, motivations, social attitudes to life and professional activities.

Psychological rehabilitation involves the provision of services such as [16]:

1) psychological diagnostics - assessment of the current psychological state and individual psychological characteristics of the recipient of services, monitoring his mental state, determining the need and optimal methods of psychological rehabilitation;

2) psychological education and information - informing the recipient of services to form an understanding of the laws of the human psyche, people's behavior in extreme conditions, the formation of skills and ways to manage the capabilities of their own psyche, self-help and first psychological assistance to others, as well as the willingness and desire to receive professional psychological assistance if necessary;

3) psychological counseling - a set of short-term measures that are carried out by a psychologist and aimed at providing the recipient with information on psychological issues, emotional support, assistance in making informed decisions and assessing their own psychological resources for behavior change, developing responsibility for their own behavior, self-awareness and change attitude to the problem, increasing stress tolerance and psychological culture;

4) psychological support and support - a system of socio-psychological methods and methods, the use of which contributes to the socio-professional selfdetermination of an individual in the course of restoring his abilities, values and self-awareness, increasing his competitiveness and adaptability, overcoming stress and other life situations and preventing the occurrence of psychological crisis conditions;

5) psychotherapy - the use of methods of psychological influence to solve personal and interpersonal problems with the use of standardized procedures in an individual or group form, aimed at restoring the impaired activity of the recipient's body to restore or compensate for its mental functions, personal qualities, interpersonal relations, and improvement quality of life;

6) group work - conducting psychological trainings, interviews, classes with psychological education and information for support groups using standardized procedures aimed at self-disclosure of participants of such groups, updating existing experience and finding ways to solve their psychological problems, developing self-knowledge and self-development skills, learning new communication and behavioral strategies [5; 14].

Physio-psychological rehabilitation services are provided to the recipient of services separately or in combination with other health, physical education, health resort, medical-psychological and social services. In accordance with the recommendations of the MSEC and taking into account domestic requirements for the development of home-based labor in the tourism infrastructure, people with disabilities may be engaged in, for example, the development of adapted tourist routes for inclusive tourists, which will contribute to the implementation of inclusive social and rehabilitation tourism in the general system of tourist services in Ukraine.

This type of rehabilitation will give an opportunity to master and further apply new types of professional and labor skills to continue working: to get a new specialty in physical abilities and get a job, to contribute to the process of creating additional jobs, including home work, which are recommended in individual rehabilitation programs for people with disabilities.

Rehabilitation of non-Olympic physical culture and sports direction

Physical rehabilitation is the systemic use of activities and physical exercises aimed at restoring the health and functional capabilities of the human body to improve the physical and psychological state through physical training and sports.

The goal of physical and sports rehabilitation activities for inclusive rehabilitators and persons with disabilities is to optimize actions aimed at integrating these categories of people into active life in society, improving their physical and functional status and restoring their working capacity by means of physical culture and sports.

In Ukraine, physical culture and sports rehabilitation activities are usually aimed at persons with disabilities 
and are carried out in accordance with the Law of Ukraine [19; 21-25].

Regarding physical and sports rehabilitation of persons with disabilities, five main types of activities are being implemented, namely [23; 27, p.131-134]:

- rehabilitation and sports fees for persons with disabilities (conducted by the Ukrainian center for physical culture and sports of disabled people Invasport)

- All-Ukrainian recreation camps for persons with disabilities (conducted by the National Committee of Disabled Sports of Ukraine);

- camps of physical culture and sports rehabilitation for persons with disabilities (conducted by the Social Protection Fund for the Disabled and the regional centers for physical culture and sports of the disabled "Invasport");

- rehabilitation and sports camps involving antiterrorist operation (ATO) fighters who were injured or disabled as a result of participation in hostilities in the east of Ukraine (conducted by the National Committee of Disabled Sports of Ukraine);

- the active rehabilitation program "Return to Life" (conducted by the All-Ukrainian Public Association "National Assembly of Disabled People of Ukraine", National Committee of Disabled Sports of Ukraine with the support of the NATO Support and Supply Office (NSPA) in Ukraine, the Ministry of Social Policy of Ukraine and the Ministry of Youth and Sports Ukraine).

\section{$\underline{\text { Life Support }}$}

rehabilitation and integration to the society due to creation the equal opportunities for self-realization

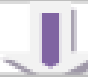

The most purposeful and active measures for physical culture and sports rehabilitation are carried out on the basis of the Western Rehabilitation and Sports Center (Yavoriv village, Turkovsky district, Lviv region), in which persons with disabilities from all regions of Ukraine take part.

In total, on the basis of the Western Rehabilitation and Sports Center in 2018 were held [1; 9]:

- 11 rehabilitation and sports gatherings, which were attended by 400 people, of which 256 people with disabilities;

- 41 sports rehabilitation camps, which were attended by 810 people, including 673 people with disabilities;

- 8 All-Ukrainian health camps for persons with disabilities, in which 104 people took part, of which 89 people with disabilities;

- 2 rehabilitation and sports gatherings with participation of antiterrorist operation (ATO) fighters, in which 34 people took part;

- 5 activities of the active rehabilitation program "Return to life", which was attended by 53 people.

Thus, physical culture and sports rehabilitation is one of the most effective ways to attract young people with disabilities to systematic physical education and sports. It allows a person with disabilities to feel their need for a team, to show their individual skills and talents and to realize themselves in society.

Discussion and conclusion

Professional assistance by means of IRST should

\section{$\underline{\text { Recreation and rehabilitation }}$}

restoration of vitality as an ordinary rehabilitate

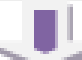

\section{The main factors which contribute to the adaptation of the disabled people due to IRST \\ Socialization \\ the development of the new methods of the touristic agencies work with the inclusive tourists

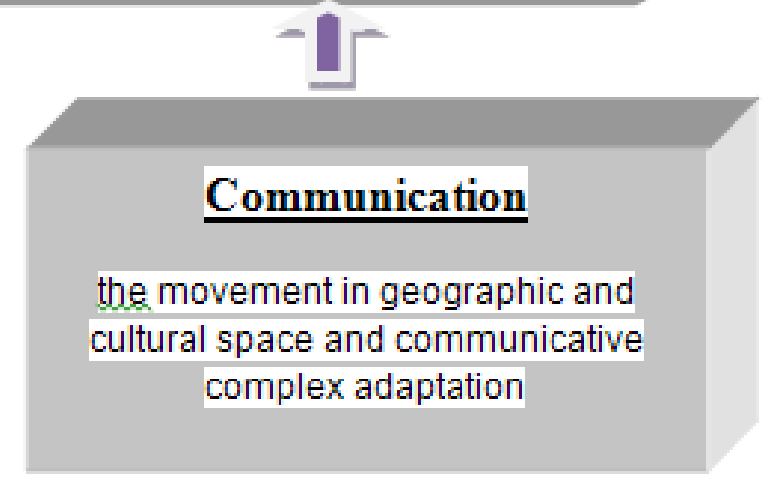

Figure 2. The main factors which contribute to the adaptation of The Persons With Disabilities (TPWD) due to Inclusive Social Rehabilitation Tourism (ISRT) 
be a powerful means of rehabilitation. It will promote healing, communication of people with different nosologies, in order to remove the existing psychological barriers with the aim of obtaining pleasure from physical activity and labor.

So, we define the following factors that limit or influence the possibility of organizing inclusive tourism (Fig. 2) [1; 18, p.75-85]:

1. Physical state of potential tourists (disability, limited capacity).

2. The financial position of potential tourists (lack of funds for the trip).

3. High transport components of a tourist trip.

4. Inflated prices for accommodation facilities.

5. The presence of bureaucratic obstacles (for example, the complexity of visa procedures for foreign travel).

6. Absence or weak development of measures for the social support of tourism and recreation.

7. The problem of poor awareness of obtaining the necessary or desired tourist product, poor marketing development.

8. The limited range of travel services and tourist destinations available for persons with disabilities.

9. The lack of necessary motivation for people to travel.

To solve these problems, the following set of measures can be proposed:

1. Creation of transport and guest structure of inclusive tourism, which includes the equipment of airports, railway and bus stations, cars and buses, special parking, lifts, travelators providing special hotel room facilities.

2. The development of medical tourism, a network of medical institutions, through which people with disabilities will be able to strengthen their health and, consequently, increase their ability to travel.

3. The development of social tourism, support for tourist activity of the population with low incomes, encouraging family and interseasonal tourism.

4. Building and improve roads, vehicles, improving the system of selling tickets. The development of a system of competing types of transport - railway, air, water, transport companies, the organization of charter transportation of passengers.

5. Expanding the network of hotels, encouraging their construction through tax breaks that individuals and legal entities have, for example, exempting the hotel from tax for a period of five years after commissioning.
6. The adoption of a state program for the development of social tourism, accessible to all.

7. Development of the information support system for tourist and excursion services accessible to people with disabilities.

8. Expansion by travel agencies and tour operators of the range of services, formation of tourist destinations in accordance with the needs of relevant groups of the population.

Conclusion. Based on the above, we can state the following:

1. Inclusive rehabilitation and social tourism is a new interdisciplinary direction, uniting various spheres of human activity (rehabilitation, treatment, psychological and professional and labor assistance, family and youth, and sports and rehabilitation segment) aimed at rehabilitating people through tourism services.

2. Thus, inclusive tourism can be considered as a form of tourism, which includes the process of cooperation between various participants in the tourism industry. This allows all inclusive categories, especially people with special needs, to be involved in tourism infrastructure using an accessible environment, including mobile, visual, auditory and cognitive components of accessibility, to function independently, on equal minds, with dignity by providing universal tourist products, services and environments.

3. Based on foreign experience of working with inclusive tourists, and first of all with people with disabilities, it is necessary to note certain steps towards the development of IRST in Ukraine as a new integrated area based on the regulatory framework of our country.

4. Despite the significant problems of creating an inclusive environment in Ukraine (lack of modern material and technical base, transport infrastructure and architectural accessibility, etc.), the availability of existing medical and recreational enterprises gives hope for the intensification of the process of introducing IRCT to provide professional assistance to rehabilitants.

5. Social and psychological rehabilitation with types of IRST will allow persons of inclusive groups to change the social role in society, master the technologies of effective functioning in various conditions of stay, socially activate themselves in the process of tourist activities, transform their outlook, develop self-care activities and care for themselves, master new knowledge and skills.

\section{References:}

1.Bielousova N. V. İnklûzivnij turizm v sistemì reabilitacìjnö̈ geografï: vìd teoriï do praktiki [Inclusive tourism in the system of rehabilitation geography: from theory to practice]. Kyiv,TALKO, 2018, 344 p. (in Ukraine).

2. Bielousova N.V. Teoretičnì aspekti rozvitku ìnklûzivnogo reabìlitacìjno-socìal'nogo turizmu v Ukraïnì [Theoretical aspects of the development of inclusive rehabilitation and social tourism in Ukraine]. Naukovij žurnal «Naukovizapiski Sums'kogo deržavnogo pedagogičnogo universitetu. Geografičnìnauki» [Scientific journal “Scientific notes of Sumy State Pedagogical University. Geographical Sciences”], 2018, Vol. 9, pp. 205-213. (in Ukrainian).

3. Bielousova N. V. «İnklûzivnij turizm» abo «podorožì bez bar'êrìv» v sučasnomu suspìl'stvì ["Inclusive tourism" or "travel without barriers" in modern society]. Ukrä̈na: geografičnij analiz ta pošuk šlâhìv virišsennâ [Ukraine: Geographic analysis and the search for solutions]. I. Pylypenko \& D. Malchikova (Eds.). Kherson: Helvetica, 2017, pp. 33-35. (in Ukrainian). 
4. Bielousova N. V. Ìnklûzivnij turizm v Ukraïnì âk vid socìokul'turnoï reabilitaciï ìnvalìdìv [Inclusive tourism in Ukraine as a kind of sociocultural rehabilitation of persons with disabilities] Social'no-gumanitarni nauki i sučasni vikliki [Social sciences and modern challenges]. Part I. O. Vysotskyi (Ed.). Dnipro: Myslyvets, 2017, pp. 219-221. (in Ukrainian).

5.Bielousova N. V. Inclusive tourism as a segment of the economy of Ukraine. World scientific extent: Collection of scientific articles. Agenda Publishing House, Coventry, United Kingdom, 2017, 424 p.

6.Culham A. Deconstructing Normalisation: Clearing the Way for Inclusion. Journal of Intellectual and Developmental Disability, Vol. 28, N. 1, 2003, pp. 65-78.

7. Grabovsky Yu. A., Skaliy O. V., Skaliy T. V. Sportyvnyy turyzm [Sports tourism]. Tutorial. Kyiv: Educational book - Bogdan, 2009, 304 p. (tables)

8. Latest IDP numbers by country. International Diplacement Monitoring Center. [Electronic source]. Access mode: http://www.internal-displacement.org/database.

9. Law of Ukraine "On the Fundamentals of Social Protection of Disabled Persons in Ukraine".

10. Law of Ukraine "On the Fundamentals of Social Protection of Children with Special Needs in Ukraine".

11. Zakonodavstvo pro pam'âtniki istorï ta kul'turi: Zbirnik normativnih aktìv [Legislation on monuments of history and culture: A collection of regulatory acts]. O. Yakimenko (ed.). Kyiv: Politvydav Ukrainy, 1970, 464 p. (in Ukrainian).

12. Report of the Ministry of social policy of Ukraine for 2017. State Statistics Service of Ukraine [Electronic source]. Access mode: www.ukrstat.gov.ua.

13. Nikitenko S. Dobrovìl'nì sportivnì tovaristva v sistemì deržavnogo upravlìnnâ fìzičnoû kul'turoû ì sportom v Ukraïnì [Voluntary sports societies in the system of state management of physical culture and sports in Ukraine]. Public administration and local self-government, 2017, Vol. 1, pp. 91-96. (In Ukrainian).

14. Pestushko V. Yu. Sučasnij stan i perspektivi rozvitku turizmu v Ukrä̈ì [Current state and prospects of tourism development in Ukraine]. Naukovì pošuki geografičnoï gromads'kostì: minule, s'ogodennâ, majbuttâ [Scientific searches in geography: past, present, future]. Luhansk, 2013, pp. 230-234. (in Ukrainian).

15. Problemy turizma: teoriya, upravleniye, innovatsii [Problems of tourism: theory, management, innovation]. Kuznetsova Yu.V. (ed.). Saint Petersburg: Asterion, 2011, 242 p. (in Russian).

16. Resolution of the Cabinet of Ministers of December 27, 2017, No. 1057, "On Approval of the Procedure for the Psychological Rehabilitation of Participants in the Antiterrorist Operation and the Victims of the Revolution of Dignity".

17. Shipko A. Vihovnij prostìr ditâčo-ûnac'kogo turizmu [Educational space for child's and adolescen's tourism]. Kraêznavstvo. Geografîa. Turizm [Local studies. Geography. Tourism], 2008, Vol. 4 (537), pp. 3-5. (in Ukrainian).

18. Teriukhanova I., Stulpinas N, Tereshchuk O. Stimulûvannâ robotodavcìv do pracevlaštuvannâ ìnvalìdìv: zarubižnij dosvìd ta vìtčiznâna praktika [Stimulation of employers for the employment of disabled people: foreign experience and domestic practice], Social'nij zahist [Social Protection], 2008, No. 11, pp. 16-17. (in Ukrainian).

19. The Law of Ukraine "On Local Self-Government in Ukraine".

20. The Law of Ukraine "On the Rehabilitation of the Disabled People in Ukraine".

21. The Law of Ukraine "On the Fundamentals of Social Protection of Children with Special Needs in Ukraine".

22. The Law of Ukraine "On the Protection of Childhood".

23. The Law of Ukraine "On State Assistance to Families with Children".

24. The Law of Ukraine "On Tourism".

25. The Law of Ukraine "On Resorts".

26. Velychko V. V. Organizaciâ rekreacìnnih poslug [Organization of recreational services]. Kharkiv: Kharkiv National University of Urban Economics, 2013, 202 p. (in Ukrainian).

27. Zakharova L. N., Kuzmina E. M., Morozova I. G. and others. Turizm kak sociokul'turnoe âvlenie [Tourism as a socio-cultural phenomenon]. Tyumen, 2003, 123 p. (in Russian).

28. Zayarnyuk A. V. Socìal'nij zahist vrazlivih verstv naselennâ: vìtčiznânij ta zarubižnij dosvìd [Social protection of vulnerable groups of the population: domestic and foreign experience]. Naukovì pracì Kirovograds'kogo nacional'nogo tehničnogo unìversitetu. Serìâ «Ekonomičnì nauki» [Scientific works of Kirovohrad National Technical University. Series "Economic Sciences"], 2004, Vol. 6, pp. 131-134. (in Ukrainian).

\section{Список використаних джерел:}

1. Бєлоусова Н. В. Інклюзивний туризм в системі реабілітаційної географії: від теорії до практики: монографія. - К.: ТАЛКОМ, 2018. - 346 с.

2. Бєлоусова Н. В. Теоретичні аспекти розвитку інклюзивного реабілітаційно-соціального туризму в Україні. Науковий журнал «Наукові записки Сумського державного педагогічного університету. Географічні науки». - Суми: СумДПУ імені А. С.Макаренко, 9-й випуск, 2018 - С.205-213;

3. Бєлоусова Н. В. «Інклюзивний туризм» або «подорожі без бар'єрів» в сучасному суспільстві. Україна: географічний аналіз та пошук шляхів вирішення: Матеріали VII Міжнародної науково-практичної 
конференції (м. Херсон, 5-6 жовтня 2017) / [Під загальною редакцією І. Пилипенко, Д. Мальчикової]. Херсон: Видавничий дім «Гельветика», 2017. - С.33-35.

4. Бєлоусова Н. В. Інклюзивний туризм в Україні як вид соціокультурної реабілітації інвалідів. Соціальногуманітарні науки і сучасні виклики. Матеріали II Всеукраїнської наукової конференції. 26-27 травня 2017, м. Дніпро. Частина І. / Наук. ред. О.Ю.Висоцький. - Дніпро: СПД «Мисливець», 2017. - С. 219-221.

5. Bielousova N. V. Inclusive tourism as a segment of the economy of Ukraine. World scientific extent: Collection of scientific articles. - Coventry: Agenda Publishing House, 2017. - 424 p.

6. Culham, A. Deconstructing Normalisation: Clearing the Way for Inclusion / Journal of Intellectual and Developmental Disability. - 2003. - Vol. 28. - N. 1, p. 65-78.

7. Грабовський Ю. А., Скалій О. В., Скалій Т. В. Спортивний туризм. Навчальний посібник. - К.: Навчальна книга - Богдан, 2009. - 304 с. (таблиці)

8.International Diplacement Monitoring Center. Latest IDP numbers bycountry. [Електронний ресурс]. - Режим доступу: http://www.internal-displacement.org/database.

9. Закон України «Про основи соціальної захищеності інвалідів в Україні» № 2249-VIII (2249-19) від 19.12.2017 р.

10. Закон України «Про основи соціальної захищеності дітей з особливими потребами в Україні» // Права дітей з особливими потребами в Україні: 3б. прав. док. - К.: Сфера, 1998. - 634 с.

11. Законодавство про пам`ятники історії та культури: Збірник нормативних актів / Під ред. О.М.Якименка. - К.: Політвидав України, 1970. - 464 с.

12. Звіт Мінсоцполітики за 2017 рік. Державна служба статистики України [Електронний ресурс]. - Режим доступу: www.ukrstat.gov.ua.

13. Нікітенко С. Добровільні спортивні товариства в системі державного управління фізичною культурою і спортом в Україні // Державне управління та місцеве самоврядування. - 2017. - Вип. 1. - С. 91-96. - Режим доступу: http://nbuv.gov.ua/UJRN/dums_2017_1_15.

14. Пестушко В.Ю. Сучасний стан і перспективи розвитку туризму в Україні //Наукові пошуки географічної громадськості: минуле, сьогодення, майбуття: матер. Всеукр. наук.-практ. конф. Луганськ: Вид-во «ДЗ ЛНУ ім.Т.Шевченка», 2013. - С.230-234.

15. Проблемы туризма: теория, управление, инновации. Монография / под ред. проф. Кузнецова Ю. В. - СПб: Астерион, 2011. - 242 с.

16. Постанова Кабінету Міністрів від 27 грудня 2017 р. № 1057 «Про затвердження Порядку проведення психологічної реабілітації учасників антитерористичної операції та постраждалих учасників Революції Гідності».

17. Шипко А. Виховний простір дитячо-юнацького туризму // Краєзнавство. Географія. Туризм. - 2008. - №4 (537). - C. 3-5.

18. Терюханова І., Стульпінас Н., Терещук О. Стимулювання роботодавців до працевлаштування інвалідів: зарубіжний досвід та вітчизняна практика // Соціальний захист. - 2008. - № 11. - С. 16-17.

19. Закон України «Про місцеве самоврядування в Україні» Відомості Верховної Ради України (ВВР), 1997, № 24, ст.170 з змінами № 2376 - VIII від 22.03.2018 р. №18, ст.168.

20. Закон України «Про реабілітацію інвалідів в Україні» (Відомості Верховної Ради України (ВВР), 2006, N 2-3, ст.36).

21. Закон України «Про основи соціальної захищеності дітей з особливими потребами в Україні». Закони України. - Т. 1. - К.: АТ «Книга», 1996. - С. 301-309.

22. Закон України «Про охорону дитинства» від 21 квітня 2001 р. № 875.

23. Закон України «Про державну допомогу сім'ям з дітьми» від 21 листопада 1992 року.

24. Закон України «Про туризм». Відомості Верховної Ради України. - 2004. - № 13, - С. 180.

25. Закон України «Про курорти» // Відомості Верховної Ради України. - 2000. - № 50. - С.22-43.

26. Величко В. В. Організація рекреаційних послуг. Навчальний посібник. - Харків: Харківський національний університет міського господарства ім. О. М. Бекетова, 2013. - 202 с.

27. Захарова Л. М., Кузьмина Е. М., Морозова И. Г. и др. Туризм как социокультурное явление / Под ред. Захаровой Л. Н. - Тюмень, 2003. - 123 с.

28. Заярнюк А. В. Соціальний захист вразливих верств населення: вітчизняний та зарубіжний досвід // Наукові праці Кіровоградського національного технічного університету. Серія «Економічні науки». - Кіровоград: КНТУ. - 2004. - Вип. 6. - С.131-134. 